\title{
Review of Our Treatment Approach in Rabies- Risky Bites in Central Anatolia
}

\author{
Iç Anadoluda Kuduz Riskli Isırıklarda Tedavi \\ Yaklaşımımızın Gözden Geçirilmesi
}

Nese Kurt Ozkaya ${ }^{1}$,

Inanc Dogan Cicek ${ }^{2}$

${ }^{1}$ Sivas Cumhuriyet University, Faculty of Medicine, Department of Plastic

Reconstructive Aesthetic Surgery, Sivas,

Turkey

2Malatya Education Research Hospital, Department of Plastic Reconstructive Aesthetic Surgery, Malatya, Turkey

Gelis Tarihi/Received: 20 June 2020

Kabul Tarihi/Accepted: 5 August 2020

Address correspondence to: Nese Kurt Ozkaya, Sivas Cumhuriyet University, Faculty of Medicine, Department of Plastic Reconstructive Aesthetic Surgery, Sivas, Turkey e-mail: ozkayanesekurt@gmail.com

\section{ORCID}

Nese Kurt Ozkaya

https://orcid.org/0000-0002-0817-1854

Inanc Dogan Cicek

https://orcid.org/0000-0001-5484-4776
Öz

Amaç: Isırıklar tüm dünyada önemli bir yaralanma sebebidir. Belli rehber ve prensiplere göre ısırıkların tedavisi yapılır. Bu çalışmada amacımız yatarak tedavi edilen ısırık yaralarının demografik özelliklerini incelemek, cerrahi tedavi deneyimlerimizi paylaşarak yeni çalışmalar ve tedaviler için yol gösterici olmaktır.

Hastalar ve Yöntem: Çalışmaya ısırık nedeniyle yatırılarak tedavi gerektiren hastalar dahil edildi. Demografik özellikleri, tetanoz ve kuduz proflaksisi, yaradan izole edilen enfeksiyon etkenleri, antibiyoterapiler, cerrahi tedaviler kaydedildi.

Bulgular: Hastaların 43 ü erkek ve ortalama yaş ( $\pm S D$ ) of $34.5 \pm 23.8$ (min3-85max). Isırıklar en sık 15 yaş altı hastalarda baş boyun bölgesinde, 15 yaş üstü hastalarda ekstremitelerde görüldü. Yaralanmaların $78.1 \%$ si köpek, $12.5 \%$ i yabani hayvan, $6.3 \%$ diğer evcil hayvan, $3.1 \%$ 'i insan kaynaklı idi. Hastaların tümüne Sağlık Bakanlığı Halk Sağlığı Genel Müdürlüğü tarafınan belirlenen Kuduz Proflaksi Rehberi'ne göre müdahele edilmişti. Tetanoz proflaksisi gereken 40 hastaya tetanoz, 62 hastaya kuduz proflaxisi ve gereken hastalara kuduz immunglobülini yapılmıştı. Hastalara proflaktik antibiyotik olarak en sık amoksisilin klavulonat, ve takiben kristalize penisilin-G başlanmıştı. $12(18.8 \%)$ hastaya geldiği gün acil cerrahi yapılmış idi. Erken ve geç onarım yapılan hastaların hiçbirinde komplikasyon görülmemişti.

Sonuç: Isırıklarda yaranın bol ve basınçlı sabunlu su ile irrigasyonu sayesinde yaranın bakteriyal yükü, acil onarım yapılmasına olanak sağlayacak kadar azaltılabilir.

Anahtar Kelimeler: Isırıklar, ısırıkların cerrahisi, kuduz proflaksi rehberi

\section{Abstract}

Aim: Bites are an essential cause of injury since the world. Treatment of bites is made according to specific guides and principles. The study's purpose is to examine the demographic characteristics of patients hospitalized due to bite wounds and to be a guide for new studies and treatments by sharing surgical treatment experiences.

Patients and Methods: Patients who were bitten and required surgical treatment were included in the study. Demographic characteristics, tetanus, and rabies prophylaxis, infection agents isolated from the wound, antibiotherapies, and surgical treatments were recorded.

Results: Of the patients, 43 were male and mean age ( \pm SD) of $34.5 \pm 23.8$ years (range, 3-85 years). Bites were most common in the head and neck region in the patients under 15 years old and In extremities in the patients over 15 years old. Of the injuries, $78.1 \%$ were caused by dogs, $12.5 \%$ by wild animals, $6.3 \%$ by other pet species, and $3.1 \%$ by humans. The intervention was made to all the patients according to guide of rabies prophylaxis specified by the Ministry of Health, General Directorate of Public Health. Forty patients received tetanus prophylaxis, 62 patients received rabies prophylaxis, and rabies immunoglobulin was applied to patients considered. The patients were started with amoxicillin-clavulanate, followed by crystallized penicillin-G as prophylactic antibiotics. Twelve $(18.8 \%)$ patient underwent an urgent operation on the date of arrival. No complication was seen in any of the patients who underwent early and late repairs.

Conclusion: Bacterial burden of the wound can be reduced enough to allow urgent repair owing to the irrigation of the wound with plenty of pressurized and soapy water in bites.

Key words: Bites, surgery of bites, rabies prophylaxis, rabies prophylaxis guide
Cite this article as: Ozkaya NK, Cicek ID. Review of Our Treatment Approach in Rabies-Risky Bites in Central Anatolia in Turkey. Selcuk Med J 2020;36(3): 178-183
Disclosure: None of the authors has a financial interest in any of the Disclosure: None of the authors has a financial interest in any of the
products, devices, or drugs mentioned in this article. The research was products, devices, or drugs mentioned in this article. The research was
not sponsored by an outside organization. All authors have agreed to allow full access to the primary data and to allow the journal to review the data if requested. 


\section{INTRODUCTION}

Bites are a serious public health problem that causes significant tissue, limb, and vital organ injuries such as nerves and veins, requiring hospitalization and surgical treatment (1-4). Such types of injuries include deep tissues, and they have tetanus, rabiesrisky contacts, and also the risk of polymicrobial infection and intoxication; therefore, first intervention and treatment are significant. As only the tissue, limb, organ injury, and treatment can be dealt with in bites, efforts are made for antidotes, compartment syndrome, and the treatment of infection and osteomyelitis in poisonous bites such as snakes and spiders (5-7).

Intervention and treatment of the bites are conducted according to the guide for rabies prophylaxis published by the Ministry of Health in Turkey and the general approach principles specified in the literature (8-10). During the wound treatment and surgery planning process, the risk of infection is high in all creatures since the oral flora of the biting creatures is polymicrobial. According to the variety of the infection agents and the oral flora of the biting species (pets, wild animal, human), the most possible infection agents and appropriate prophylactic antibiotherapy options are determined in the relevant studies (8-11). Although urgent surgery is recommended for surgical treatment due to the infection agents and risk, it is also an issue of concern to decide for an early repair in the injuries with a high risk of infection $(1,10,12)$.

In this study, our aim is to be a guide in clinical practices with our surgical treatment experiences and the results we have achieved in bite wounds treated and hospitalized in our clinic.

\section{PATIENTS AND METHODS}

This study included a series of 64 patients with animal or human bites who underwent surgery between August 2007 and December 2017. All patients underwent surgery and medical treatment in the plastic surgery inpatient clinic. For this retrospective study, local ethics committee approval was obtained from our institution, and all processes were realized by the Declaration of Helsinki. Patients with hospitalization indicate that surgical repair is planned due to deep tissue damage after an urgent examination was included in the study. The patients have applied to the emergency department or the outpatient clinic on the first day after the injury, the wound sites were irrigated with plenty of pressurized water by applying local block anesthesia if necessary. The wound was examined to see whether or not there was any deep tissue, muscle, major veins, nerve, tendon, joint, and bone damage. According to the rabies prophylaxis guide and the current principles, tetanus and rabies prophylaxis are performed by the emergency team for rabies immunoglobulin to the required patients and prophylactic antibiotics are started. In the case of wound follow up, the patient is followed up for three days as of the date of hospitalization for debridement, dressing, and prophylactic antibiotics. After three days, microbiological sampling is taken, surgical repair is applied to the patients, at whom bacteria could not be isolated as a result of the culture. Postoperative follow-up is done at the service. The patients whose demographics, surgery, and medical treatment information were not available from the archive database were excluded from the study. Demographic and clinical data of the patients such as age, gender, the type of the animal, location of the injury, emergency treatment, medical therapy, vaccination for tetanus and rabies risk contact, sensory and motor nerve dysfunction accompanying the wound were recorded. The type of surgery performed, and the time from trauma to surgery, microbiological culture results, and postoperative complications were recorded for contamination and infection. The data obtained were analyzed. The descriptive statistics were assessed in number (n) and percentage (\%) for categorical variables. The median (minimum-maximum) and standard deviation values were used for the continuous variable.

\section{RESULTS}

Of 487 patients who applied to the emergency department between August 2007 and December 2017 due to the complaint of bite, 64 were hospitalized at the department of plastic reconstructive and aesthetic surgery and treated. All the patients applied within 24 hours after the bite. Of the patients, 21 were female, and 43 were male. The mean age $( \pm S D)$ of the patients was $34.5 \pm 23.8$ years (range, 3-85 years). Twenty patients $(31.3 \%)$ were between the age of 3-15 years. In terms of location of the injury, $13(65 \%)$ and $7(35 \%)$ of the patient under the age of 15 had injury in the head and neck region and the extremity, respectively. On the other hand, $12(27.3 \%)$ and 28 $(63.6 \%)$ of the patients over 15 years old had an injury in the head and neck region and the extremity, respectively. $1(2.3 \%)$ of them had injury in both face and extremity, and $3(6.8 \%)$ patients had an injury in body and extremity. According to the type of the 
Table 1. Demographic characteristics of patients, $\mathrm{n}=64$

\begin{tabular}{ll}
\hline$\%$ & \\
\hline Female/Male & $21(32.8) / 43(67.2)$ \\
Age (mean) & $34.5(3-85)$ \\
Under/Over 15 years old & $20(31.3) / 44(68.7)$ \\
Location of injury & \\
(Under/Over 15 years old) & $13(65) / 12(27.3)$ \\
$\quad$ head-face-neck & $7(35) / 28(63.6)$ \\
$\quad$ extremities & $/ 1(2.3)$ \\
$\quad$ face and extremities & $/ 3(6.8)$ \\
body and extremities & $50(78.1)$ \\
Cause of trauma & $8(12.5)$ \\
$\quad$ dog bites & $4(6.3)$ \\
$\quad$ wild animal bites & $2(3.1)$ \\
$\quad$ other pets species & \\
human bites & $12(18.9)$ \\
Chronic Disease & $10(15.6)$ \\
$\quad$ Hypertension &
\end{tabular}

biting creature, $50(78.1 \%)$ were dog bites, $8(12.5 \%)$ were wild animal bites (7 pigs, one wolf), 4 (6.3\%) were other domestic species (horse, donkey, cow), and $2(3.1 \%)$ were human bites. (Table 1$)$. When the patients' chronic disease histories were questioned, ten patients had diabetes, and 12 patients had hypertension.

It was determined that the routine tetanus vaccination protocol of the patients under 18 years continued, and three patients over 18 years old were not vaccinated again because their tetanus prophylaxis protocol was completed previously. During the initial examination, all the patients were irrigated with plenty of pressurized soapy water. Forty patients received tetanus prophylaxis. Two patients with lower extremity injuries were not vaccinated due to the previous administration of rabies prophylaxis. Rabies prophylaxis was started for the remaining

Table 2. Distribution of prophylactic vaccine, and antibiotic types administered after patients are hospitalized $(n=64)$

\begin{tabular}{ll}
\hline Prophylactic Vaccines & $\mathrm{n}(\%)$ \\
Tetanus prophylaxis & $40(62.5)$ \\
Rabies prophylaxis/Immunglobulin & $62(96.9) / 62$ \\
& $(96.9)$ \\
Prophylactic antibiotics & 38 \\
amoksisilin klavulonik asit & 12 \\
kristalize penisilin G & 6 \\
sultamisilin & 6 \\
sultamisilin ve aminoglikozit & 2 \\
sefazolin sodyum & \\
\hline
\end{tabular}

62 patients, and rabies immunoglobulin was applied to suitable patients. After the patients were hospitalized, prophylactic antibiotics were started for all the patients. The first choice was amoxicillin clavulanate, regardless of the bite agent as a prophylactic antibiotic. Antibiotics recommended by the department of pediatrics in pediatric patients were started. Combined antibiotherapy was started in patients with a full-thickness injury reaching the mucosa around the mouth or nose, or with deep injury to other parts of the body. The prophylactic antibiotics used were found to compatible with current rabies prophylaxis guidelines (8). Amoxicillin clavulanate was started as a prophylactic in 38 patients, crystallized penicillin-G in 12 , sultamicillin in 6 , sultamicillin and aminoglycoside combination in 6 , and cefazolin treatment in 2 were started (Table 2 ). In only $2(3.1 \%)$ patients, the antibiotic used was changed according to the microbiological sampling taken on the 3rd posttraumatic day.

On the day of the arrival, 12 (18.8\%) patients were urgently taken into operations due to the reasons such as replantation, aesthetic reasons, and bleeding, and no culture sampling was done. When the results of the culture samples taken from the wound sites of the patients on the 3rd day of hospitalization were evaluated, no bacteria was isolated in 40 (62.5\%) of the patients with dog bites. Staphylococcus epidermidis was isolated in $7(10.9 \%)$ in the wounds of the patients, streptococcus dysgalactiae/canis, corynebacterium striatum, enterococcus faecalis, proteus vulgaris, and pseudomonas aeruginosa isolated in each in the wounds of 5 patients $(1(1.6 \%)$ ) (Table 3). Staphylococcus epidermidis in 1 patient with pig bite and corynebacterium striatum bacterias in 1 patient were isolated. In all other wounds that bacteria were isolated, the reason for the bite was

Table 3. Microbiological agents isolated from patients' wounds $(n=64)$

\begin{tabular}{ll}
\hline Microbiological agents & $\mathbf{n}(\%)$ \\
\hline no isolated bacteriae & $40^{*}(62.5)$ \\
no culture & $12(18.8)$ \\
staphylococcus epidermidis & total:7(10.9) \\
& $\left(6^{*}-1 \dagger\right)$ \\
staphylococcus dysagalactia/canis & $1(1.6)^{*}$ \\
corynobacterium striatum & $1(1.6) \dagger$ \\
enterococcal fecalis & $1(1.6)^{*}$ \\
proteus vulgaris & $1(1.6)^{*}$ \\
pseudomonas aeruginosa & $1(1.6)^{*}$ \\
${ }^{*}$ dog bites, †pig bites & \\
\hline
\end{tabular}




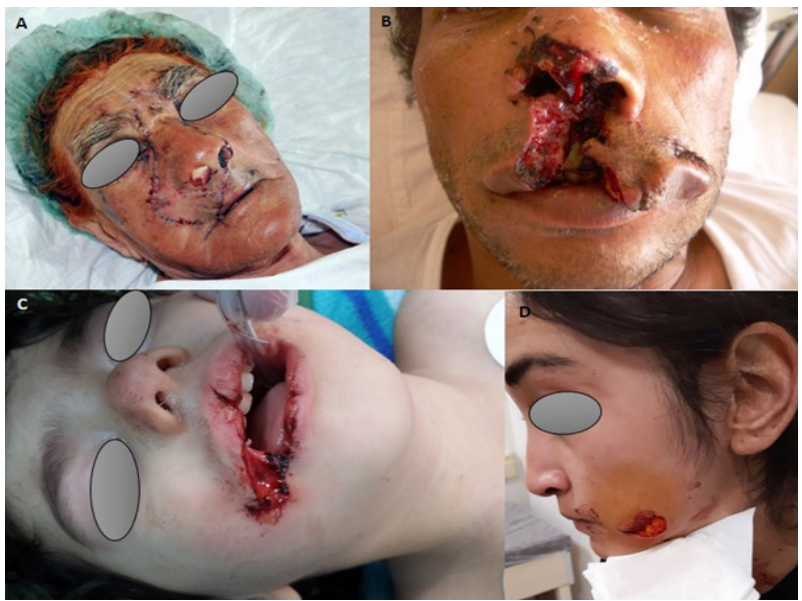

Figure 1. A; The view of second postoperative day after replantation with both angular artery and vein anastomosis of the patient, who have a total nasal amputation including both medial canthus, nasal cartilage dorsum, and the right half of the upper lip as of glabella as a result of the dog bite, $B$; view of the patient having a subtotal amputation in the nasal tip and the left half of the upper lip as a result of horse bite, C; Locally full-layer injury including peroral right oral commissure as a result of dog bite, D; skin subcutaneous segmental incision as a result of a human bite.

the dog. In these patients, appropriate antibiotherapy was given according to the antibiogram test results. In the cases where bacteria were isolated in the culture, daily irrigation and antibiotherapy were performed, and bacteriological culture was examined at intervals, and surgical closure was applied after determining that the bacteria was not isolated.

In our study, almost all bite species caused vital tissue injuries. The reason for the injury-causing nasal amputation was a dog bite, while the reason for ear amputation was a human bite, femoral artery injury was caused by pig bite, and peroneal nerve damage occurred as a result of a wolf attack (Figure $1 \mathrm{~A}, \mathrm{~B}, \mathrm{C}, \mathrm{D})$. When the surgical methods and repairs applied were evaluated, it was determined among the people to whom repair was conducted on the first day, seven patients had primary suturation, had a local flap, one patient underwent ear replantation, one patient underwent nasal replantation, one patient had femoral artery repair in addition to primary suturation, and one patient had peroneal nerve repair. Among the remaining 52 patients, the skin graft was applied to 4 , primary suturation to 35 , local flap to 17, and paramedian forehead flap to 2 patients. No infection, tissue loss, flap necrosis, or dehiscence in the sutures were observed in any of the patients to whom reconstruction was applied on the first day or according to the result of the culture.

\section{DISCUSSION}

In the present study, including the animal- and human-induced rabies risk contact bites in the patients hospitalized and surgically treated at the department of plastic surgery, it was observed that men were injured more frequently with a rate of $67.2 \%$. This rate was compatible with other studies in Turkey $(5,13-15)$. The studies have emphasized that the high rate of male patients is associated with the fact that men spend more time in the outer environment. No conclusion could be drawn due to the limitations of the current data. It may also be a reason that agriculture and animal husbandry are common due to Turkey's geographic location and an "Anatolian Sheepdog (Kangal)" in almost every house in the countryside. Anatolian Sheepdog is a breed of dog that is specific to the region of the study and known with its strong jaw structure (16). There are many differences in results obtained from the studies on age range when rabies-risky contact is mostly observed. There are publications $(5,17)$ reporting that children, especially individuals under the age of 15 years $(14,15)$. Or adults are more often injured. In the present study, the rate of patients over 15 years of age was higher.

The body area injured due to bite varies according to the type of biting creature and the age of the injured (17). While injuries in the head and neck region were dominant in the patients under 15 years of age, they were more in the extremities over 15 years of age. In adults, trauma frequently occurs in the extremities due to the use of these areas for defense (17). As the most common reason for injury is a dog bite, this is followed by wild animal species. In numerous studies conducted in Turkey and abroad, cat bites take place in the second rank among the causes of the bite $(2,11,14,18)$; however, no cat bite was observed in the present study. As noted in other studies, this is because cat bites are minor traumas and that do not require surgical repair by hospitalization at the plastic reconstructive aesthetic surgery clinic (9). Deep tissue damage occurred in all the injuries. No correlation was found between the bite species (dog, wild animal, human, etc.) and the depth of injury. All bite factors damaged either a vital organ injury or deep vital anatomical structures. This information was compatible with the literature $(2,3,4,9)$. Although it has been reported that the human bites are located 
in the hands, arms, and shoulders in men, they are located in the chest, legs, and arms in women, and they were located in the face and ear in the present study (5). (Figure 1A, B, C, D)

In Turkey, accepted as an endemic region in terms of rabies, it is reported that approximately 250.000 rabies-risk contacts and an average of 1-2 rabies cases are seen per year (8). In rabies-risky injuries, intervention and vaccination are carried out in accordance with the directive set by the public health department of the Ministry of Health. This directive is renewed periodically. When the current intervention of our hospital was evaluated, all practices were following these guidelines. Considering the bacteria isolated according to the results of microbiological sampling, the results of our study were not compatible with the bacteria isolated in the literature, and their isolation rates (19). Bacteria could not be isolated in $40(62.5 \%)$ of the patients. In patients where bacteria were isolated, only one type of bacteria was isolated instead of polymicrobial growth. Antibiotherapy by the department of infectious diseases was not recommended in 6 patients $(9.4 \%)$ with isolated Staphylococcus epidermidis.

When the patients who underwent surgery on the first day and those whose bacteria could not be isolated were evaluated together, no isolated bacteria was found in $58(90.6 \%)$ patients. This finding emphasizes the importance of abundant pressure irrigation in the first intervention.

This study has limitations. These limitations are that the number of patients was small, immunization rates of the patients included in the vaccination program could not be followed, and the patients were not assessed in terms of the scar and psychosocial aspects in the long term. In this retrospective epidemiological study, only the data we could obtain was evaluated. Studies involving infection rates and isolated bacteria can be performed according to more comprehensive, standardized bite species. The difference in the patients and the biting species and the differences from the literature in the isolated bacteria species as a result of the microbiological examination enrich the current study. It is believed that data obtained differently from the literature will guide further multi-centered and prospective studies in the future. However, our study is a valuable study especially in terms of good washing and early surgical approach. Moreover, despite different bite species and depths, it is a valuable study that shows that effective and successful treatment is performed thanks to the intervention and standard antibiotherapy according to the Rabian Prophylaxis guide of the Ministry of Health.

As a result, emergency surgery and early repair can be performed if rabies risk bites are washed with plenty of pressurized water in the first intervention and if the rabies prophylaxis guide specified by the Ministry of Health is followed.

Conflict of interest: Authors declare that there is no conflict of interest between the authors of the article.

Financial conflict of interest: Authors declare that they did not receive any financial support in this study.

Address correspondence to: Nese Kurt Ozkaya, Cumhuriyet University, Faculty of Medicine, Department of Plastic Reconstructive and Aesthetic Surgery, 58140 Sivas, Turkey,

Fax: +903462580032

E-mail: ozkayanesekurt@gmail.com,

Phone number: +905053890745

\section{REFERENCES}

1. Chávez-Serna E, Andrade-Delgado L, Martínez-Wagner R, et al. Experience in the management of acute wounds by dog bite in a hospital of third level of plastic and reconstructive surgery in Mexico. Experiencia en el manejo de heridas por mordedura de perro en un hospital de tercer nivel de cirugía plástica y reconstructiva en México. Cir Cir 2019;87(5):52839.

2. Demirtaş E, Güler S, Duymaz H, et al. Evaluation of animal- related injuries from the perspective of 7423 cases admitted to Emergency Department. Cumhuriyet Tıp Dergisi 2016;38(1);40-5.

3. Shah S, Bansal H, Mittal RK, et al. An unusual dog bite in an infant with penetrating brain injury and scalp loss. Turk Plast Surg 2019;27(1):30-2.

4. Dadaci M, Gundeslioğlu AO, Ince B, et al. Successful microsurgical revascularization of an almost totally amputated ear lobe by horse bite. J Craniofac Surg 2014;25(1):e82-4.

5. Köse AA, Uzuner M. Plastik cerrahide ısırık yaralanmaları ve yılan sokmaları. Turkiye Klinikleri J Plast Surg-Special Topics 2017;6(1):97-104

6. Ince B, Altuntaş Z, Dadacı M. Development of osteomyelitis secondary to a snakebite: Case report. Arch Clin Exp Surg 2016;5:180-3.

7. Ince B, Dadacı M, Altuntaş Z, et al. The management of viperidae envenomation. Turk Plast Surg 2015:23(1):1-5.

8. Kuduz Profilaksi Rehberi, T.C. Sağlık Bakanlığı Halk Sağlığı Genel Müdürlüğü, Yayın no: 1134, Ankara, 2019.

9. Aziz H, Rhee P, Pandit V, et al. The current concepts in management of animal (dog, cat, snake, scorpion) and human bite wounds. J Trauma Acute Care Surg 2015;78(3):641-8.

10. Hurt JB, Maday KR. Management and treatment of animal bites. JAAPA 2018;31(4):27-31.

11. Rothe K, Tsokos M, Handrick W. Animal and human bite wounds. Dtsch Arztebl Int 2015;112(25):433-43. 
12. Wu PS, Beres A, Tashjian DB, et al. Primary repair of facial dog bite injuries in children. Pediatr Emerg Care 2011;27(9):8013.

13. Yılmaz F, Akbulut AS, Taş M, et al. Evaluation of cases with rabies risk presenting to emergency department. J Clin Anal Med 2014;5:8-11.

14. Aydın E, Yılmaz Y, Aydın S, et al. Íkinci basamak sağlık kurumuna müracaat eden kuduz şüpheli temas vakalarının değerlendirilmesi. Kafkas J Med Sci 2016;6(2):98-101.

15. Özer Balin Ş, Denk A. Kuduz riskli temas bildirimlerinin değerlendirilmesi. Firat Med J 2016;21(3):141-4.
16. Özbeyaz K. Kangal köpeklerinde bazı morfolojik özellikler. Lalahan Hay Araşt Enst Derg 1994;34(1-2):38-46.

17. Gündüz T, Elçioğlu Ö, Balcı Y. An evaluation of dog and cat bites over a five-year period: A sample case from Eskişehir. Ulus Travma Acil Cerrahi Derg 2011;17(2):133-40.

18. Bregman B, Slavinski S. Using emergency department data to conduct dog and animal bite surveillance in New York City, 2003-2006. Public Health Rep 2012;127(2):195-201.

19. Fredrick MA, Ellie JC. Goldstein. Microbiology of animal bite wound infections. Clin Microbiol Rev 2011;24(2):231-46. 